\section{A letter to Soviet scientists}

The following document reached Nature on 21 May 1981, the 61st birthday of Academician Andrei Sakharov.

I have learned from foreign broadcasts that the "Scientists for Sakharov, Orlov and Shcharanskii" (SOS) Committee in the United States has issued an appeal to Soviet scientists to come to the defence of the family of Sergei Kovalev - that is, Sergei himself, his daughter-in-law Tat'yana Osipova, and his son Ivan. I feel sure that many of you also heard this appeal. I beg you to treat it with all seriousness and to undertake those actions to which each of you feels prompted by his feeling of responsibility as a citizen and by his conscience, both in this particular case, and in others where your intervention would be of special importance.

For many years now, I have observed an almost total lack of action on the part of my Soviet scientific colleagues in matters relating to the defence of human rights. It is shamefu that foreign scientists (and deepest thanks to them!) show a greater concern for our affairs than we do ourselves. In this letter, I am speaking first and foremost to those scientists occupying a fairly high and independent position - more specifically to Members and Corresponding Members of the Academies. I know that some of you have negative or sceptical feelings regarding my statements on general questions. But this is not a general question (on these, I have always expressed my views in the form of a discussion, and have never thrust my opinions on to anyone). This is a matter of the fate of real people, including the fate of your colleague in science. Every one of you who has shown even the least interest will form his or her own independent opinions on these cases, of the total degree of injustice and the harshness of repression.

You cannot consider that these cases do not touch you; the historical experience of our country, professional solidarity, simple human sympathy for the fate of others, and often personal contact with the victims of repression (many of you were personally acquainted with Orlov, Kovalev and others), make such an attitude impossible. You must not invoke the interests of your job, the need to keep your professional post in the interests of science. In fact, most of you are in a fairly secure position. And the interests of science must include the defence of members of the scientific community from injustice; they include the responsibility of the citizen. This is not the Stalin era; practically speaking none of you now are under any kind of threat. But can you rule out completely a return to a new era of mass repression? For if this should come to pass, your lack of action now will be one of the causes. And conversely, could not the activity as citizens and the independence of even a few of the country's top scientists have a profound and beneficial effect on the whole situation?

And which of you can lay his hand on his heart and proclaim that this is not a vital necessity? It is precisely this which more than anything would promote international scientific relations, and, on a far far wider scale, trust and peace throughout the world.
Such is the measure of the individual personal responsibility of every one of you.

In conclusion, I should like to cite severa] examples of scientists and scholars who are victims of repression - prisoners of conscience. For each of these cases there is information which is accessible to you.

(1) The case of Kovalev and his family, with which I began this letter. Kovalev has served a term of seven years imprisonment under the harshest conditions, and he is now in exile, under shocking conditions in the Magadan region. Tanya Osipova and Ivan Kovalev are in prison, and it is necessary to obtain for them, at the very least, the opportunity of meeting. After the arrest of his wife, and before his own arrest, Ivan had only one 30-minute meeting with her in 15 months. (2) The case of Yurii Orlov. His fate, and the cruel torments he is suffering are widely known.

(3) The case of Anatolii Shcharanskii - also very well known.

(4) The case of the mathematician and cyberneticist, Dr Aleksandr Bolonkin. After imprisonment and exile which robbed him of nine years of his life, beatings-up, confinement in the punishment cells and provocations, he is back in prison again on a trumped-up crimina charge.

(5) The case of the philologist and poet, Vasyl Stus'. After many years in prison and exile, he was condemned to a further 15 years labourcamp and exile, simply for supporting the Ukrainian Helsinki Watch Group.

(6) The case of Anatolyi Marchenko. He is not a scholar; he is a worker and writer, the author of some remarkable books on presentday labour camps and prisons. But he has been sentenced again - his fifth sentence to the monstrous term of 15 years imprisonment and five years exile; the central point of the charge being his open and noblehearted letter on the "Sakharov case" to academician P. L. Kapitsa, who is one of those to whom $I$ address this letter.

(7) The cases of Aleksandr Lavut and Tat'yana Velikanova (mathematicians), Mart Niklus (ornithologist), Leonard Ternovskii (radiologist), Viktor Nekipelov (a pharmacist and talented poet), Pyatkus (philologist), Meilanov (mathematician), Luk'yanenko (jurist), Airikyan, Altunyan and many others. None of them has had recourse to violence nor would do so. All of them have suffered cruelly for loyalty to their noble convictions, the principles of free expression and justice. Help them - this is our common duty.

Andrei Sakharov, Gor'kii, 30 March 1982.

POSTSCRIPT - In defence of Ivan Kovalev.

Ivan Kovalev has been sentenced. This is yet another blow to the champions of human rights in the Soviet Union, to free expression, and to the Helsinki Watch Group; a blow against the principles expressed in the Helsink Final Act. And this is a new act of inconceivable cruelty towards the famous Kovalev family, the third of its victims. In December 1974, Sergei Kovalev, Ivan's father, was arrested. In May, 1980, Tat'yana Osipova, Ivan's wife was arrested. Both of them, like Ivan Kovalev himself, have received cruel sentences for their nonviolent defence of human rights, for their fidelity to noble convictions. In a letter which he wrote shortly before his arrest, Ivan Kovalev wrote about himself and his situation. And in his article "My Tanya", he told us about his wife, her fate and her struggle. There is little one can add to those documents - and having known Ivan for many years I am convinced of the justice of his case.

I call upon everyone who believes in justice, who can feel for the tragedy of this young family, to speak out in defence of Ivan Kovalev, his wife and, of course, his father. The possibility of a meeting between Tat'yana and Ivan must be obtained - this is their inalienable human right. And it is very important too to obtain their freedom, and the freedom of all prisoners of conscience. Andrei Sakharov, Gor'kii, 2 April 1982.

\section{ESA clarification}

SIR - May I refer to your article "Antarctic research hit by crisis" published in Nature of 15 April (p.593) and in particular to the part of the article:

"Although Argentina's own research efforts have been extremely limited, it is at present collaborating with the French in glaciological work, and plans exist to site a ground station for the first European Space Agency remote sensing satellite to be put into polar orbit, at the Argentinian base of Marambio",

There is no Argentinian connection with the European Space Agency/ERS-1 programme. There will certainly be some ERS-1 overseas ground-stations outside Europe, but no negotiations have been made with Argentina or indeed with any other South American state. If such plans were ever envisaged, they would require approval of ESA Council.

You will appreciate ESA's desire to have this point clarified.

W. BRADO

(Head of ESA Director General's Cabinet)

ESA, Paris, France

\section{Editor in false garb}

SIR - If both of your bizarre and intemporate recent leading articles ("Doves in false garb", 18 February, p.542; and "Professional propaganda", 1 April, p.380) had been published on 1 April, one might more easily have understood them. They are so full of rancid sarcasm, repetition to the point of perseveration, wild claims devoid of any supportive evidence, multiple errors in basic logic, frank contradictions and odd grammar, that they imply a writer almost incoherent with anger. They are also probably the most disgraceful abuses of editorial privilege I have ever seen in print.

You have used, however ineffectually, the anonymity of the editorial and the prestige of a hitherto distinguished scientific journal, to lend spurious respectability and authority to your personal and highly idiosyncratic views. You have jeered at a very large number of sincere, ethical, distinguished and honourable professionals throughout the world, impugning their honesty, without raising a 